\title{
KUALITAS PELAYANAN, FAKTOR EMOSIONAL DAN PERSEPSI HARGA TERHADAP LOYALITAS KONSUMEN MELALUI KEPUASAN KONSUMEN
}

\author{
Marida Yulia Ronasih ${ }^{1}$, Hardani Widhiastuti ${ }^{2}$ \\ 1,2) Magister Psikologi Universitas Semarang \\ Jl. Soekarno Hatta, Tlogosari Kulon, Kec. Pedurungan, Semarang, Jawa Tengah 59160 \\ e-mail: ${ }^{1}$ marida.psikologi11@gmail.com, ${ }^{2}$ dhani_fpsi@usm.ac.id
}

Article History:

Received

26 April 2021

Review

19 Mei 2021

Revised

31 Mei 2021

Accepted

4 Juni 2021

Published

23 Juni 2021

Reviewer:

Muhammad Abd Hadi Bunyamin
Abstract. The purpose of this study was to determine the effect of service quality, emotional factors and price perceptions on consumer loyalty through customer satisfaction. This research used quantitative methods with incidental sampling techniques, 75 total of samples who are in PPIU Asshodiqiyah Semarang City. Testing of hypothesis used path analysis techniques processed with the SmartPLS 3.0 program. The results showed that 1) The service quality had a positive and significant effect on customer satisfaction; 2) emotional factors had a positive and significant effect on customer satisfaction; 3) price perceptions had a positive and significant effect on customer satisfaction; 4) the quality of services had a positive and significant effect on consumer loyalty; 5) emotional factors had no significant effect on consumer loyalty; 6) price perceptions had no significant effect on consumer loyalty; 7) customer satisfaction had a positive and significant effect on customer loyalty; 8) quality of service had no significant effect on consumer loyalty through customer satisfaction; 9) emotional factors had a positive and significant effect on customer loyalty through customer satisfaction; 10) price perceptions had no significant effect on consumer loyalty through customer satisfaction.

Keywords: service quality, emotional factors, price perception, customer satisfaction, customer loyalty.

Abstrak. Tujuan dari penelitian ini adalah untuk mengetahui pengaruh kualitas pelayanan, faktor emosional dan persepsi harga terhadap loyalitas konsumen melalui kepuasan konsumen. Penelitian menggunakan metode kuantitatif dengan teknik pengambilan sampling insidental, dengan jumlah 75 sampel yang berada di PPIU Asshodiqiyah Kota Semarang. Pengujian hipotesis menggunakan teknik analisis jalur yang diolah dengan program SmartPLS 3.0. Hasil penelitian menunjukkan bahwa 1) kualitas pelayanan berpengaruh positif dan signifikan terhadap kepuasan konsumen; 2) faktor emosional berpengaruh positif dan signifikan terhadap kepuasan konsumen; 3) persepsi harga berpengaruh positif dan signifikan terhadap kepuasan konsumen; 4) kualitas pelayanan berpengaruh positif dan signifikan terhadap loyalitas konsumen; 5) faktor emosional tidak berpengaruh signifikan terhadap loyalitas konsumen; 6) persepsi harga tidak berpengaruh signifikan terhadap loyalitas konsumen; 7) kepuasan konsumen berpengaruh positif dan signifikan terhadap loyalitas konsumen; 8) kualitas pelayanan tidak berpengaruh signifikan terhadap loyalitas konsumen melalui kepuasan konsumen; 9) faktor emosional berpengaruh positif dan 
signifikan terhadap loyalitas konsumen melalui kepuasan konsumen; 10) persepsi harga tidak berpengaruh signifikan terhadap loyalitas konsumen melalui kepuasan konsumen.

Kata kunci: kualitas pelayanan, faktor emosional, persepsi harga, kepuasan konsumen, loyalitas konsumen.

\section{Pendahuluan}

Umrah merupakan kegiatan ibadah dalam agama Islam. Pengertian umrah secara harfiah berarti berkunjung. Tujuan ibadah umrah pada dasarnya adalah untuk mengharapkan rahmat Tuhan Yang Maha Esa. Seiring berjalannya waktu dan perkembangan jaman, ibadah umrah kini menjadi trend umat muslim khususnya di Indonesia. Tujuan murni ibadah umrah pun bergeser menjadi perjalanan wisata. Beberapa biro perjalanan umrah menarik perhatian konsumen dengan tambahan fasilitas wisata religi ke beberapa negara tetangga Arab Saudi. Selain adanya trend tersebut, pendaftar jamaah ibadah umrah di Indonesia juga terus mengalami peningkatan disebabkan karena masa tunggu pelaksanaan ibadah haji yang lama dan biaya yang relatif terjangkau. Banyaknya minat masyarakat untuk melaksanakan ibadah umrah kini menarik perhatian banyak pihak untuk menjalankan bisnis di bidang perjalanan umrah. Tercatat di Bulan Desember 2020 terdapat 1.200 Penyelenggara Perjalanan Ibadah Umrah (PPIU) di seluruh Indonesia (Kemenag, 2020).

Banyaknya pesaing dalam bisnis ini menjadi tantangan bagi biro PPIU untuk mempertahankan konsumennya. Pada dasarnya, mempertahankan konsumen merupakan orientasi jangka panjang yang menjadi tujuan utama setiap bisnis. Hal tersebut menjadikan konsumen yang loyal merupakan aset berharga bagi perusahaan. Secara harfiah, loyal diartikan setia sedangkan loyalitas adalah kesetiaan. Konsumen yang loyal terhadap suatu produk atau jasa tertentu cenderung terikat pada merek atau jasa tersebut. Dalam konteks jasa, loyalitas konsumen didefinisikan oleh Bendapudi \& Berry (Tjiptono, 2014) sebagai respon yang terikat erat dengan ikrar atau janji untuk memegang teguh komitmen yang mendasari kontinuitas relasi, dan biasanya tercermin dalam pembelian berkelanjutan dari penyedia jasa yang sama atas dasar dedikasi maupun kendala pragmatis.

Berdasarkan pemaparan tersebut, loyalitas konsumen pada dasarnya lebih penting untuk diperhatikan dibandingkan dengan mencari konsumen baru yang sifatnya hanya jangka pendek. Mewujudkan loyalitas konsumen tentunya butuh usaha supaya dapat menumbuhkan "keterikatan" konsumen ditengah banyaknya pesaing di bidang yang sama. Biro PPIU Asshodiqiyah merupakan salah satu biro PPIU di Kota Semarang yang telah 
memiliki ribuan jamaah haji dan umrah sejak tahun 1985. Biro PPIU Asshodiqiyah cenderung lebih konvensional dibandingkan dengan biro-biro lain dalam bidang yang sama meskipun pengalamannya sudah mencapai 35 tahun. Pembimbing PPIU Asshodiqiyah memiliki cara tersendiri untuk mempertahankan konsumennya. Strategi yang dilakukan terbukti dengan adanya sejumlah jamaah yang menggunakan jasa PPIU Asshodiqiyah lebih dari satu kali bahkan beberapa jamaah selalu menggunakan jasanya setiap tahun. Hal ini dapat dikatakan bahwa terdapat loyalitas konsumen pada beberapa jamaah di biro PPIU Asshodiqiyah.

Total jamaah umrah sejak tahun 1985 hingga 2019 sudah mencapai ribuan jamaah. Meskipun sudah memiliki banyak jamaah, strategi untuk mempertahankan jamaah tersebut perlu ditingkatkan mengingat adanya banyak pesaing saat ini. Hal ini perlu untuk diteliti lebih lanjut karena dalam tiga tahun terakhir jumlah jamaah Biro PPIU Asshodiqiyah mengalami penurunan. Berdasarkan data yang peneliti dapatkan, berikut adalah grafik jumlah jamaah umrah Biro PPIU Asshodiqiyah dari tahun 2017 sampai dengan tahun 2019:

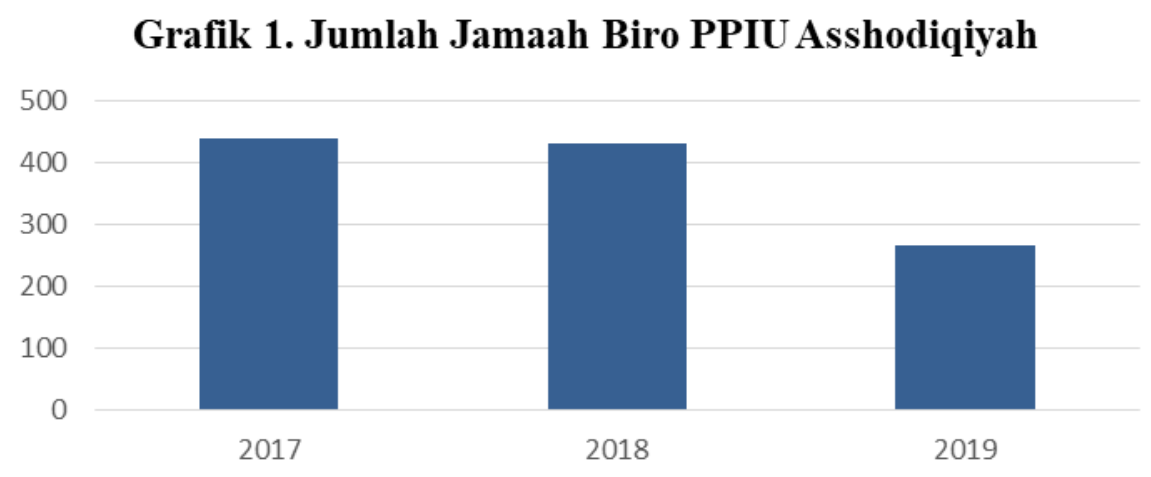

Sumber : PT. Asshodiqiyah Terboyo Haji dan Umrah (data diolah peneliti)

Berdasarkan grafik di atas, terlihat bahwa jumlah jamaah dari tahun 2017 sampai dengan tahun 2019 mengalami penurunan. Tahun 2017, jumlah jamaah biro PPIU Asshodiqiyah adalah sebanyak 440. Tahun 2018, jumlah jamaah mengalami penurunan menjadi 432. Tahun 2019 masih mengalami penurunan bahkan hampir menurun 50\% dengan jumlah jamaah menjadi 296.

Penurunan jumlah jamaah tersebut tentunya dipengaruhi oleh beberapa faktor. Menurut Suryati (2019) faktor yang mempengaruhi loyalitas konsumen adalah kepercayaan, kepuasan, dan biaya peralihan. Tjiptono (2014) mengungkapkan bahwa kepuasan konsumen berkontribusi pada sejumlah aspek krusial, salah satunya adalah terciptanya loyalitas konsumen. Hal ini didukung oleh penelitian Erwin \& Sitinjak (2017) 
yang menemukan hasil bahwa kepuasan konsumen berpengaruh positif dan signifikan terhadap loyalitas konsumen. Sejalan dengan hal tersebut, penelitian yang dilakukan oleh Molle dkk (2019) juga menunjukkan kepuasan memiliki pengaruh yang signifikan terhadap loyalitas konsumen.

Kepuasan konsumen merupakan salah satu kunci untuk mempertahankan konsumen. Aspek dari kepuasan konsumen meliputi harapan, kinerja, perbandingan, pengalaman, konfirmasi dan diskonfirmasi (Priansa, 2017). Konsumen yang sangat puas biasanya tetap setia untuk waktu yang lebih lama (Kotler \& Keller, 2009). Kepuasan konsumen cukup banyak digunakan peneliti untuk mengungkap pengaruhnya terhadap loyalitas konsumen. Rivai \& Wahyudi (2017) melakukan penelitian untuk melihat pengaruh persepsi kualitas, citra merek, persepsi harga terhadap loyalitas pelanggan dengan kepercayaan dan kepuasan pelanggan sebagai variabel mediasi. Hasilnya adalah kepuasan pelanggan berpengaruh sangat signifikan terhadap loyalitas pelanggan, sedangkan kepercayaan kurang berpengaruh terhadap loyalitas pelanggan.

Penelitian lain yang dilakukan Aulawi (2016) juga menunjukkan bahwa apabila konsumen merasa puas, maka konsumen akan setia. Mayoritas penelitian mengenai kepuasan konsumen menunjukkan pengaruh yang signifikan terhadap loyalitas konsumen. Berbeda dengan hal tersebut, Griffin (2016) menemukan beberapa penelitian yang menunjukkan bahwa tingkat kepuasan konsumen yang tinggi belum tentu menghasilkan pembelian berulang dan peningkatan penjualan. Hal tersebut bisa saja terjadi karena terdapat beberapa faktor lain yang dapat mempengaruhi loyalitas konsumen selain kepuasan konsumen.

Kepuasan konsumen harus ditingkatkan serta dipertahankan dalam jangka panjang supaya loyalitas dapat meningkat pula. Untuk menciptakan hal tersebut, perusahaan perlu memahami apa yang penting dan menjadi kebutuhan konsumen, salah satunya adalah kualitas pelayanan. Menurut Irawan (2003) terdapat lima faktor yang mempengaruhi kepuasan konsumen yaitu kualitas produk, harga, kualitas pelayanan, faktor emosional, dan kemudahan. Akbar (2019) melakukan penelitian mengenai pengaruh kualitas pelayanan, sarana dan prasarana terhadap kepuasan serta dampaknya terhadap loyalitas konsumen. Hasil dari penelitian tersebut menunjukkan bahwa kualitas pelayanan, sarana dan prasarana secara simultan maupun parsial berpengaruh terhadap kepuasan dan loyalitas pelanggan.

Penelitian lain yang mendukung hal diatas dilakukan oleh Sari (2017, hal. 26) dalam penelitiannya mengungkapkan bahwa konsumen merasa kualitas pelayanan yang 
diberikan sudah baik sesuai dengan persepsi mereka sehingga menimbulkan rasa puas pada konsumen. Menurut Parasuraman dkk (Lupiyoadi, 2017) kualitas pelayanan memiliki lima aspek penting untuk diukur yaitu berwujud, kehandalan, daya tanggap, jaminan, dan empati. Meski memiliki pengaruh terhadap kepuasan konsumen, penelitian yang dilakukan Meesala \& Paul (2016, hal. 8) menemukan bahwa hanya 2 dari 5 aspek kualitas pelayanan yaitu keandalan dan daya tanggap berdampak pada kepuasan pasien. Hal tersebut dikarenakan terdapat beberapa faktor lain yang dapat mempengaruhi kepuasan konsumen, salah satunya adalah faktor emosional.

Emosi memiliki peran penting dalam mewujudkan kepuasan dan loyalitas konsumen. Fondasi loyalitas adalah menunjang kepuasan konsumen, ini adalah hubungan emosional dan sikap, bukan sekedar perilaku. Kepuasan yang dirasakan konsumen ketika berhubungan dengan para pelaku bisnis sangat dipengaruhi oleh sentuhan emosi dari hubungan tersebut. Prediktor terbaik dari keseluruhan kepuasan konsumen dalam berhubungan dengan seorang pelaku bisnis adalah taraf kesuksesan pelaku bisnis dalam menciptakan emosi positif konsumen (Barnes J. , 2003).

Hal diatas didukung oleh penelitian Prihatin dkk (2018, hal. 103) yang menemukan bahwa faktor emosi berpengaruh positif dan signifikan terhadap kepuasan pelanggan. Hal ini mengindikasikan bahwa semakin tinggi faktor emosi maka akan semakin tinggi kepuasan pelanggan. Faktor emosi terbukti berpengaruh terhadap kepuasan pelanggan. Selain hubungannya dengan kepuasan konsumen, Amanah \& Harahap (2019, hal. 23) memperkuat hal tersebut dengan penelitiannya yang mengungkapkan bahwa nilai emosional secara langsung berpengaruh positif terhadap loyalitas konsumen. Aspek faktor emosional menurut Pourazad, Stocchi \& Pare (2019, hal. 2) meliputi brand love, brand attachment, brand passion, self-brand Identification.

Rangkuti (2003, hal. 30) menyebutkan persepsi dan harga merupakan prediktor lain yang berpengaruh terhadap kepuasan konsumen selain kualitas pelayanan dan faktor emosional yang telah dijelaskan diatas. Persepsi menurut King (2017) adalah proses mengorganisasi dan menginterpretasikan informasi sensoris agar informasi tersebut menjadi bermakna. Aspek dari persepsi terdiri dari seleksi dan interpretasi (Sobur, 2003). Sedangkan harga dalam konteks pemasaran jasa dapat diartikan sebagai jumlah uang (satuan/moneter) dan/atau aspek lain (non-moneter) yang mengandung utilitas atau kegunaan tertentu yang berpotensi memuaskan kebutuhan dan keinginan tertentu (Tjiptono, 2014). Hal tersebut menjelaskan bahwa persepsi terhadap harga merupakan 
bagaimana konsumen memproses/menilai harga berdasarkan manfaat yang akan didapatkan.

Harga rendah dan harga tinggi akan dipersepsikan secara berbeda pada tiap konsumen. Bagi konsumen yang sensitif, biasanya harga murah adalah sumber kepuasan yang penting karena mereka akan mendapatkan value for money yang tinggi (Irawan H. , 2003). Namun beberapa konsumen juga tidak mempermasalahkan harga mahal apabila apa yang didapatkan sesuai dengan harga yang telah dibayarkan. Savitri \& Wardana (2018) mendukung dengan penelitiannya yang menemukan bahwa tingkat harga yang relatif mempunyai skor tertinggi. Artinya, konsumen menganggap perusahaan memiliki harga yang relatif sesuai dengan yang didapatkan oleh konsumennya.

Berdasarkan pemaparan di atas, peneliti melihat loyalitas konsumen biro PPIU Asshodiqiyah penting untuk diteliti lebih lanjut mengingat adanya penurunan jumlah konsumen selama tiga tahun terakhir. Penurunan jumlah konsumen tersebut dapat dipengaruhi oleh loyalitas konsumen. Menurut Griffin (2016) apabila konsumen loyal, maka mereka akan menunjukkan perilaku yang menguntungkan pihak perusahaan berdasarkan aspek dari loyalitas konsumen yaitu (1) melakukan pembelian berulang secara teratur, (2) membeli antarlini produk dan jasa, (3) mereferensikan kepada orang lain, (4) menunjukkan kekebalan terhadap tarikan dari pesaing.

Salah satu aspek yang berperan besar adalah mereferensikan dan mengajak orang lain untuk menggunakan produk/jasa tersebut, sehingga semakin banyak konsumen yang loyal seharusnya dapat meningkatkan jumlah konsumen pula. Situasi ini sering kita dengar dengan istilah gethok tular yaitu penyebaran informasi dari mulut ke mulut. Hasil wawancara awal kepada 5 konsumen di PPIU Asshodiqiyah ditemukan bahwa mereka telah mereferensikan kepada orang lain dan menyebarkan informasi positif mengenai namun jumlah konsumen di PPIU Asshodiqiyah masih mengalami penurunan.

Pemaparan di atas menunjukkan betapa pentingnya loyalitas konsumen terhadap keberlangsungan suatu bisnis, namun terdapat kesenjangan antara teori dengan keadaan di lapangan. Hal ini penting untuk diteliti lebih lanjut supaya perusahaan dapat bertahan untuk mencapai hasil yang maksimal serta menghindari adanya penurunan jumlah konsumen.

\section{Metode}


Metode penelitian ini menggunakan pendekatan kuantitatif. Populasi yang digunakan dalam penelitian ini adalah Jamaah Penyelenggara Perjalanan Ibadah Umroh (PPIU) Asshodiqiyah Kota Semarang yang pernah mengikuti ibadah umrah minimal 1 kali. Sampel dalam penelitian ini berjumlah 75 konsumen dengan teknik sampling insidental, yaitu teknik penentuan sampel berdasarkan kebetulan atau siapa saja yang secara kebetulan/insidental bertemu dengan peneliti dimana orang yang kebetulan ditemui cocok sebagai sumber data (Sugiyono, 2018). Metode pengumpulan data menggunakan skala loyalitas konsumen, skala kepuasan konsumen, skala kualitas pelayanan, skala faktor emosional, dan skala persepsi harga. Analisis data diolah menggunakan program SmartPLS 3.0 dengan teknik analisis jalur karena analisis jalur dapat menguji hubungan langsung antar variabel maupun hubungan tidak langsung antar variabel dalam model (Ghozali \& Latan, 2015).

\section{Hasil}

\section{Validitas}

Validitas diskriminan dinilai berdasarkan crossloading pengukuran dengan konstruk. Jika korelasi konstruk dengan item pengukuran lebih besar daripada ukuran konstruk lainnya maka konstruk laten memprediksi ukuran pada blok mereka lebih baik daripada ukuran pada blok lainnya (Ghozali, 2014). Rule of thumb untuk menilai validitas diskriminan yaitu dengan melihat nilai crossloading untuk setiap variabel harus lebih dari 0.7 (Ghozali \& Latan, 2015)

Tabel 1. Validitas Diskriminan Variabel Penelitian

\begin{tabular}{lrrlrl}
\hline & $\begin{array}{l}\text { Faktor } \\
\text { Emosional }\end{array}$ & $\begin{array}{l}\text { Kepuasan } \\
\text { Konsumen }\end{array}$ & $\begin{array}{l}\text { Kualitas } \\
\text { Pelayanan }\end{array}$ & $\begin{array}{l}\text { Loyalitas } \\
\text { Konsumen }\end{array}$ & $\begin{array}{l}\text { Persepsi } \\
\text { Harga }\end{array}$ \\
\hline $\begin{array}{l}\text { Faktor } \\
\text { Emosional }\end{array}$ & $\mathbf{0 . 7 9 9}$ & & & & \\
\hline $\begin{array}{l}\text { Kepuasan } \\
\text { Konsumen }\end{array}$ & 0.705 & $\mathbf{0 . 8 3 5}$ & & & \\
\hline $\begin{array}{l}\text { Kualitas } \\
\text { Pelayanan }\end{array}$ & 0.577 & 0.692 & $\mathbf{0 . 8 0 9}$ & & \\
\hline $\begin{array}{l}\text { Loyalitas } \\
\text { Konsumen }\end{array}$ & 0.651 & 0.817 & 0.715 & $\mathbf{0 . 8 2 8}$ & \\
\hline $\begin{array}{l}\text { Persepsi } \\
\text { Harga }\end{array}$ & 0.693 & 0.718 & 0.620 & 0.721 & $\mathbf{0 . 8 3 2}$ \\
\hline
\end{tabular}


Berdasarkan tabel di atas, semua variabel dinyatakan valid karena nilai korelasi dari suatu variabel lebih besar daripada nilai korelasi variabel tersebut terhadap variabel lainnya.

\section{Reliabilitas}

Uji reliabilitas dilakukan untuk membuktikan akurasi, konsistensi dan ketepatan instrumen dalam mengukur konstruk. Pengukuran reliabilitas dapat dilakukan dengan dua cara yaitu Cronbach's Alpha dan Composite Reliability. Rule of thumb untuk menilai composite reliability yaitu nilai composite reliability harus lebih besar dari 0.7 untuk penelitian yang bersifat confirmatory dan $0.6-0.7$ untuk penelitian yang bersifat explanatory, sedangkan nilai Cronbach's Alpha harus lebih besar dari 0.7 untuk penelitian yang bersifat confirmatory dan 0.6 untuk penelitian yang bersifat explanatory (Ghozali \& Latan, 2015).

Tabel 2. Reliabilitas Variabel Penelitian

\begin{tabular}{lcccc}
\hline & $\begin{array}{l}\text { Cronbach's } \\
\text { Alpha }\end{array}$ & rho_A & $\begin{array}{c}\text { Composite } \\
\text { Reliability }\end{array}$ & (AVE) \\
\hline Loyalitas Konsumen & 0.965 & 0.965 & 0.968 & 0.685 \\
\hline Kepuasan Konsumen & 0.971 & 0.972 & 0.973 & 0.697 \\
\hline Kualitas Pelayanan & 0.965 & 0.966 & 0.968 & 0.654 \\
\hline Faktor Emosional & 0.956 & 0.957 & 0.961 & 0.639 \\
\hline Persepsi Harga & 0.950 & 0.953 & 0.957 & 0.691 \\
\hline
\end{tabular}

Berdasarkan tabel di atas, semua variabel dinyatakan reliabel karena nilai composite reliability lebih besar dari 0,7 atau bisa juga cronbach's alpha lebih besar dari 0,6.

\section{Uji Hipotesis}

Uji hipotesis dalam penelitian ini diproses menggunakan SmartPLS 3.0. Teknik yang digunakan adalah teknik analisis jalur. Teknik ini merupakan pengembangan dari analisis regresi berganda. Tujuan dari pemilihan teknik analisis jalur adalah karena penelitian ini menggunakan variabel intervening. Analisis jalur dapat menguji hubungan langsung antar variabel maupun hubungan tidak langsung antar variabel dalam model (Ghozali \& Latan, 2015). 
Gambar 3. Model Hasil Penelitian (P Values)

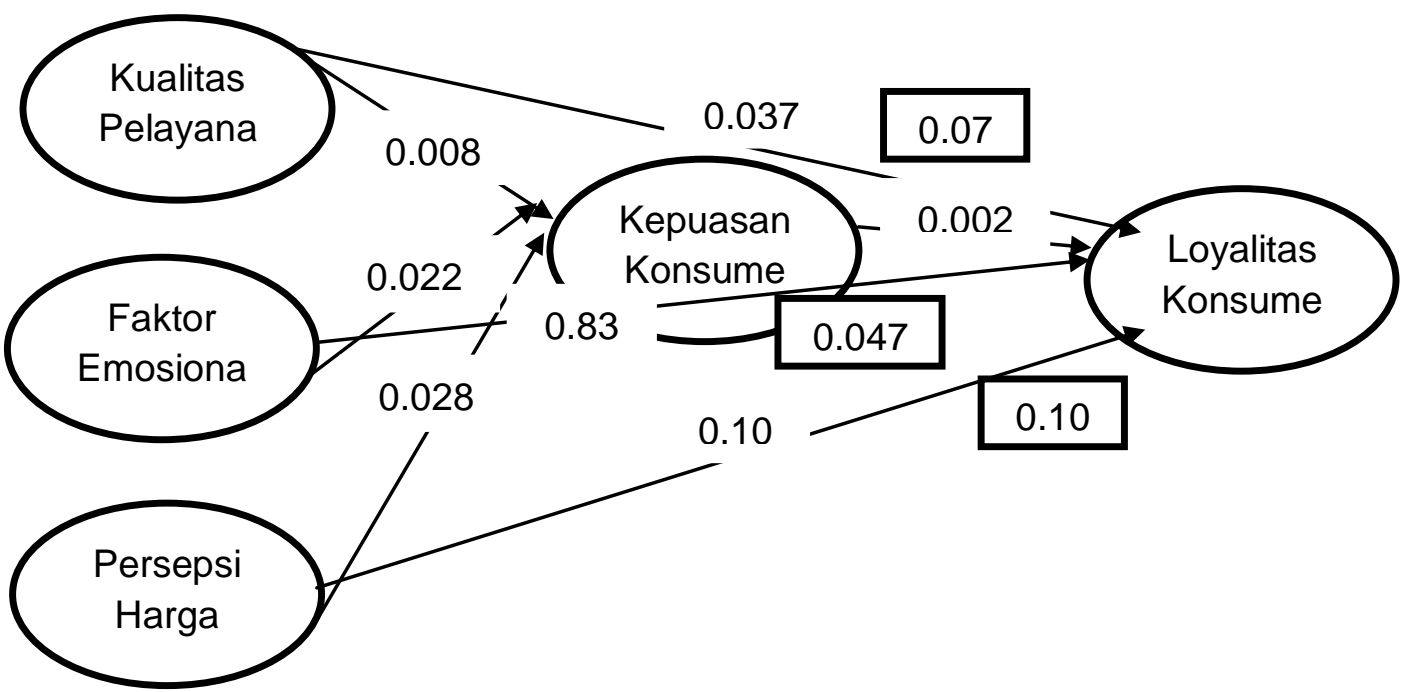

Keterangan :

$* \quad=$ Signifikan

$\square=$ Pengaruh tidak langsung (melalui mediasi)

Berikut adalah tabel rincian hasil uji hipotesis yang telah diolah menggunakan program SmartPLS 3.0 :

Tabel 3. Hasil Pengujian Hipotesis

\begin{tabular}{lccccc}
\hline & $\begin{array}{l}\text { Original } \\
\text { Sample (0) }\end{array}$ & $\begin{array}{l}\text { Sample } \\
\text { Mean (M) }\end{array}$ & $\begin{array}{l}\text { Standard } \\
\text { Deviation } \\
\text { (STDEV) }\end{array}$ & $\begin{array}{l}\text { T Statistics } \\
(\mid \text { O/STDEV } \mid)\end{array}$ & P Values \\
\hline $\mathrm{KP} \rightarrow \mathrm{KK}$ & 0.329 & 0.333 & 0.123 & 2.673 & 0.008 \\
\hline $\mathrm{FE} \rightarrow$ KK & 0.306 & 0.292 & 0.133 & 2.293 & 0.022 \\
\hline $\mathrm{PH} \rightarrow \mathrm{KK}$ & 0.302 & 0.312 & 0.137 & 2.200 & 0.028 \\
\hline $\mathrm{KP} \rightarrow \mathrm{LK}$ & 0.232 & 0.216 & 0.111 & 2.091 & 0.037 \\
\hline $\mathrm{FE} \rightarrow$ LK & 0.032 & 0.052 & 0.152 & 0.213 & $\mathbf{0 . 8 3 1}$ \\
\hline $\mathrm{PH} \rightarrow$ LK & 0.207 & 0.190 & 0.128 & 1.615 & $\mathbf{0 . 1 0 7}$ \\
\hline $\mathrm{KK} \rightarrow$ LK & 0.484 & 0.499 & 0.156 & 3.094 & 0.002 \\
\hline $\mathrm{KP} \rightarrow \mathrm{KK} \rightarrow$ LK & 0.159 & 0.170 & 0.090 & 1.759 & $\mathbf{0 . 0 7 9}$ \\
\hline $\mathrm{FE} \rightarrow$ KK $\rightarrow$ LK & 0.148 & 0.140 & 0.074 & 1.995 & 0.047 \\
\hline $\mathrm{PH} \rightarrow \mathrm{KK} \rightarrow$ LK & 0.146 & 0.158 & 0.089 & 1.643 & $\mathbf{0 . 1 0 1}$
\end{tabular}

Keterangan :

LK : Loyalitas Konsumen

KK : Kepuasan Konsumen

KP : Kualitas Pelayanan

FE : Faktor Emosional

PH : Persepsi Harga 
Berdasarkan tabel di atas, kualitas pelayanan berpengaruh positif dan signifikan terhadap kepuasan konsumen karena nilai t statistics sebesar 2,673 dimana lebih besar dari $\mathrm{t}$ tabel $=1,96$ dan juga $\mathrm{p}$ values sebesar 0,008 dimana lebih kecil dari 0,05. Hal tersebut menunjukkan bahwa $\mathrm{H} 1$ diterima.

Faktor emosional berpengaruh positif dan signifikan terhadap kepuasan konsumen karena nilai t statistics sebesar 2,293 dimana lebih besar dari t tabel $=1,96$ dan juga $\mathrm{p}$ values sebesar 0,022 dimana lebih kecil dari 0,05. Hal tersebut menunjukkan bahwa H2 diterima.

Persepsi harga berpengaruh positif dan signifikan terhadap kepuasan konsumen karena nilai $t$ statistics sebesar 2,200 dimana lebih besar dari $t$ tabel $=1,96$ dan juga $p$ values sebesar 0,028 dimana lebih kecil dari 0,05. Hal tersebut menunjukkan bahwa H3 diterima.

Kualitas pelayanan berpengaruh positif dan signifikan terhadap loyalitas konsumen karena nilai t statistics sebesar 2,091 dimana lebih besar dari t tabel $=1,96$ dan juga $p$ values sebesar 0,037 dimana lebih kecil dari 0,05. Hal tersebut menunjukkan bahwa H4 diterima.

Faktor emosional tidak berpengaruh signifikan terhadap loyalitas konsumen karena nilai $\mathrm{t}$ statistics sebesar 0,213 dimana lebih kecil dari $\mathrm{t}$ tabel $=1,96$ dan juga $\mathrm{p}$ values sebesar 0,831 dimana lebih besar dari 0,05. Hal tersebut menunjukkan bahwa H5 ditolak.

Persepsi harga tidak berpengaruh signifikan terhadap loyalitas konsumen karena nilai $\mathrm{t}$ statistics sebesar 1,615 dimana lebih kecil dari t tabel = 1,96 dan juga $\mathrm{p}$ values sebesar 0,107 dimana lebih besar dari 0,05. Hal tersebut menunjukkan bahwa H6 ditolak.

Kepuasan konsumen berpengaruh positif dan signifikan terhadap loyalitas konsumen karena nilai t statistics sebesar 3,094 dimana lebih besar dari t tabel $=1,96$ dan juga $p$ values sebesar 0,002 dimana lebih kecil dari 0,05. Hal tersebut menunjukkan bahwa H7 diterima.

Kualitas pelayanan tidak berpengaruh signifikan terhadap loyalitas konsumen melalui kepuasan konsumen karena nilai t statistics sebesar 1,759 dimana lebih kecil dari t tabel = 1,96 dan juga $\mathrm{p}$ values sebesar 0,079 dimana lebih besar dari 0,05. Hal tersebut menunjukkan bahwa kepuasan konsumen tidak dapat memediasi pengaruh kualitas pelayanan terhadap loyalitas konsumen, sehingga H8 ditolak.

Faktor emosional berpengaruh positif dan signifikan terhadap loyalitas konsumen melalui kepuasan konsumen karena nilai t statistics sebesar 1,995 dimana lebih besar dari $\mathrm{t}$ tabel $=1,96$ dan juga $\mathrm{p}$ values sebesar 0,047 dimana lebih kecil dari 0,05. Hal tersebut 
menunjukkan bahwa kepuasan konsumen dapat memediasi pengaruh faktor emosional terhadap loyalitas konsumen, sehingga H9 diterima.

Persepsi harga tidak berpengaruh signifikan terhadap loyalitas konsumen melalui kepuasan konsumen karena nilai $t$ statistics sebesar 1,643 dimana lebih kecil dari $\mathrm{t}$ tabel = 1,96 dan juga $\mathrm{p}$ values sebesar 0,101 dimana lebih besar dari 0,05. Hal tersebut menunjukkan bahwa kepuasan konsumen tidak dapat memediasi pengaruh persepsi harga terhadap loyalitas konsumen, sehingga H10 ditolak.

\section{Diskusi}

\section{Pengaruh Kualitas Pelayanan terhadap Kepuasan Konsumen}

Hasil analisis data menunjukkan bahwa kualitas pelayanan berpengaruh positif dan signifikan terhadap kepuasan konsumen. Hasil tersebut sejalan dengan penelitian terdahulu oleh Pakurar, Haddad, Nagy, Pop, \& Olah (2019); Le, Nguyen, \& Truong (2019); Afthanorhan, Awang, Rashid, Foziah, \& Ghazali (2019) bahwa seluruh dimensi kualitas pelayanan berpengaruh positif dan signifikan terhadap kepuasan konsumen.

Hasil penelitian di atas konsisten dengan yang dikemukakan Irawan (2003) yang menyatakan bahwa kualitas pelayanan merupakan salah satu faktor yang dapat mempengaruhi tingkat kepuasan konsumen. Sejalan dengan hal tersebut, Rangkuti (2003) menjelaskan bahwa kepuasan konsumen ditentukan oleh berbagai jenis pelayanan yang didapatkan oleh konsumen selama konsumen menggunakan beberapa tahapan pelayanan tersebut. Pelayanan dengan kualitas yang baik akan membuat konsumen merasa puas. Pelayanan dianggap baik atau berkualitas apabila pelayanan yang diterima sesuai atau bahkan melebihi harapan konsumen.

\section{Pengaruh Faktor Emosional terhadap Kepuasan Konsumen}

Hasil analisis data menunjukkan bahwa faktor emosional berpengaruh positif dan signifikan terhadap kepuasan konsumen. Hasil tersebut sejalan dengan penelitian terdahulu oleh Prihatin, Mursito, \& Wijayanti (2018); Moreo, Woods, Sammons, \& Bergman (2018) serta Ritonga, Pane, \& Rahmah (2020) bahwa faktor emosi berpengaruh terhadap kepuasan konsumen.

Hasil penelitian di atas konsisten dengan teori yang disampaikan Indrasari (2019) bahwa emosional konsumen merupakan salah satu hal yang dapat mempengaruhi kepuasan konsumen. Sependapat dengan hal tersebut, Barnes (2003) menyatakan kepuasan konsumen adalah suatu emosi yang dihasilkan dari penilaian atas rangkaian pengalaman. Hal tersebut mengartikan bahwa respon emosional merupakan bagian dari proses terciptanya kepuasan konsumen. 
Philanthropy Journal of Psychology

Vol 5 Nomor 1 (2021), 109-130

ISSN 2580-6076 (Print), ISSN 2580-8532 (Online)

\section{Pengaruh Persepsi Harga terhadap Kepuasan Konsumen}

Hasil analisis data menunjukkan menunjukkan bahwa persepsi harga berpengaruh positif dan signifikan terhadap kepuasan konsumen. Hasil tersebut sejalan dengan penelitian terdahulu oleh Nurrahman, Eldine, \& Muniroh (2019); Winarno, Nalendra, \& Bryan (2020) serta Salim, Soliha, \& Siswanto (2020) yang menyatakan bahwa persepsi harga berpengaruh terhadap kepuasan konsumen. Hal tersebut menunjukkan apabila harga yang ditetapkan dianggap sesuai oleh konsumen maka akan memberikan kepuasan pada konsumen.

Hasil penelitian di atas konsisten dengan teori yang disampaikan oleh Rangkuti (2003) bahwa persepsi konsumen terhadap jasa berpengaruh terhadap tingkat kepuasan konsumen. Lebih lanjut, persepsi terhadap harga dipengaruhi oleh beberapa hal salah satunya adalah harga. Hal tersebut menjelaskan bahwa persepsi harga berpengaruh terhadap kepuasan konsumen. Konsumen yang sensitif biasanya menganggap harga murah adalah sumber kepuasan yang penting karena mereka akan mendapatkan value for money yang tinggi. Sebaliknya, bagi konsumen yang tidak sensitif, komponen harga ini menjadi relatif tidak penting (Irawan, 2003).

Konsumen yang tidak sensitif terhadap harga biasanya menilai harga berdasarkan kesesuaian manfaat yang diterima. Konsumen akan merasa puas apabila harga yang ditawarkan sesuai dengan manfaat yang diterima berdasarkan kebutuhan konsumen itu sendiri. Harga menjadi subjektif dalam menentukan kepuasan konsumen, bahkan pada sejumlah situasi konsumen rela membayar harga yang lebih mahal demi menekan biaya non-moneter seperti menghemat waktu, mendapatkan kenyamanan yang lebih besar, terhindar dari kerepotan yang tidak perlu, dan sebagainya (Tjiptono, 2014).

\section{Pengaruh Kualitas Pelayanan terhadap Loyalitas Konsumen}

Hasil analisis data menunjukkan bahwa kualitas pelayanan berpengaruh secara positif dan signifikan terhadap loyalitas konsumen. Hasil tersebut sejalan dengan penelitian terdahulu (Othman, Harun, Taha, Aref, \& Sadq, 2020) yang menyatakan bahwa seluruh dimensi kualitas pelayanan memiliki hubungan yang positif dan signifikan dengan loyalitas konsumen. Kualitas pelayanan merupakan faktor penting dalam pembentukan loyalitas konsumen namun penekanan terhadap faktor lain yang berinteraksi satu sama lain perlu dilakukan untuk lebih menumbuhkan loyalitas.

Hasil penelitian di atas konsisten dengan teori yang dikemukakan oleh Barnes (2003) yang menyatakan memberikan pelayanan yang luar biasa adalah salah satu cara perusahaan untuk membuatnya disayangi oleh konsumen. Setelah melakukan pembelian, 
konsumen semakin peduli dengan pelayanan dan bagaimana mereka diperlakukan saat membeli sesuatu. Hal tersebut menunjukkan bahwa kualitas dari pelayanan merupakan hal penting untuk menjalin hubungan baik dengan konsumen. Memelihara hubungan konsumen merupakan dasar dari banyak strategi untuk meningkatkan loyalitas konsumen (Griffin, 2016).

\section{Pengaruh Faktor Emosional terhadap Loyalitas Konsumen}

Hasil analisis data menunjukkan bahwa faktor emosional tidak berpengaruh signifikan terhadap loyalitas konsumen. Hasil tersebut sejalan dengan penelitian yang dilakukan oleh Sari, Priyatama, \& Satwika (2019) yang menyatakan bahwa tidak terdapat hubungan yang signifikan antara hubungan emosional dengan loyalitas konsumen secara parsial. Hasil yang berbeda ditemukan pada penelitian yang dilakukan Iksanudin, Puspitasari, \& Ariningsih (2019) serta Repiannur, Rachma, \& Khoirul (2020) yang menyatakan bahwa kedekatan emosional konsumen berpengaruh positif dan signifikan terhadap loyalitas konsumen.

Hasil di atas bertolak belakang dengan pernyataan Barnes (2003) bahwa emosi dan perasaan konsumen sangat berpengaruh terhadap keputusan konsumen untuk terus berbisnis dengan perusahaan di masa depan. Hubungan yang paling dekat antara konsumen dengan perusahaan ditandai sebagai hubungan yang bersifat pribadi, akrab dan seringkali melibatkan penyingkapan informasi pribadi. Ketika konsumen menjadi lebih dekat secara emosional, ada efek positif pada interaksi konsumen dengan perusahaan, salah satunya adalah terbentuknya loyalitas konsumen.

Pemaparan di atas menjelaskan bahwa menciptakan hubungan emosional yang positif dengan konsumen merupakan salah satu strategi untuk menumbuhkan loyalitas konsumen. Meski begitu faktor emosional tidak menjadi faktor penentu dalam mewujudkan loyalitas. Penelitian yang dilakukan Susanti, Sumarwan, Simanjuntak, \& Yusuf (2020) menunjukkan bahwa faktor emosional memiliki pengaruh terhadap loyalitas konsumen namun pengaruh yang dimiliki cukup lemah dibandingan dengan faktor lain dalam penelitian tersebut.

Terdapat beberapa perusahaan yang telah berbisnis dalam waktu yang lama dengan konsumen, namun bukan dikarenakan adanya hubungan emosi atau perasaan loyal, tetapi karena hadiah-hadiah, harga atau keengganan untuk berpindah. Berdasarkan definisi, mereka bukanlah konsumen dengan loyalitas sejati. Hubungan tersebut didasarkan pada insentif negatif atau rintangan yang menghalangi konsumen untuk keluar (Barnes J. G., 2003). 
Philanthropy Journal of Psychology

Vol 5 Nomor 1 (2021), 109-130

ISSN 2580-6076 (Print), ISSN 2580-8532 (Online)

\section{Pengaruh Persepsi Harga terhadap Loyalitas Konsumen}

Hasil analisis data menunjukkan bahwa persepsi harga tidak berpengaruh signifikan terhadap loyalitas konsumen. Hasil tersebut sejalan dengan penelitian Widyasari, Soliha, Wuryan, \& Damayanti (2017) serta Sulistiyanto \& Munisih (2018) yang menemukan hasil bahwa persepsi harga tidak berpengaruh terhadap loyalitas konsumen. Penelitian terdahulu dengan hasil berbeda dikemukakan oleh Irawan, Sulistyono, \& Tanjung (2019) yang menyatakan bahwa persepsi harga berpengaruh positif dan signifikan secara parsial terhadap loyalitas konsumen.

Hasil penelitian ini bertolak belakang dengan teori yang dikemukakan Tjiptono (2014) bahwa nilai harga merupakan salah satu determinan utama yang menyebabkan seorang konsumen loyal pada suatu perusahaan. Nilai harga merupakan kesesuaian harga dengan kualitas atau manfaat yang diterima. Tujuan dari penetapan harga yang sesuai dengan kebutuhan atau manfaat yang didapat konsumen adalah untuk menghargai dan mempertahankan konsumen yang loyal (Tjiptono, 2014).

Irawan (2003) menyatakan bahwa konsumen yang sensitif, biasanya harga murah adalah sumber kepuasan yang penting karena mereka akan mendapatkan value for money yang tinggi. Sebaliknya, bagi konsumen yang tidak sensitif, komponen harga ini menjadi relatif tidak penting. Sensitivitas terhadap harga sangatlah subyektif dan cenderung bervariasi dalam berbagai produk dan situasi (Barnes J. G., 2003).

Beberapa hal yang menyebabkan konsumen tidak terlalu sensitif terhadap harga adalah ketika hanya ada sedikit barang atau tidak ada pengganti atau pesaing, konsumen tidak siap untuk memperhatikan harga yang lebih tinggi, konsumen cenderung lambat untuk mengubah kebiasaan pembelian mereka, konsumen berpikir harga yang lebih tinggi itu sudah benar, dan yang terakhir harga adalah bagian kecil dari total biaya mendapatkan, mengoperasikan, dan memperbaiki produk sepanjang umur hidup produk (Kotler \& Keller, 2009).

\section{Pengaruh Kepuasan Konsumen terhadap Loyalitas Konsumen}

Hasil analisis data menunjukkan bahwa kepuasan konsumen berpengaruh positif dan signifikan terhadap loyalitas konsumen. Hasil tersebut sejalan dengan penelitian Chou, Kohsuwan, \& Thanabordeekij (2019); serta Djajanto, Afiatin, \& Haris (2019) yang menemukan hasil bahwa kepuasan konsumen berpengaruh signifikan terhadap loyalitas konsumen. Hal tersebut menunjukkan bahwa tingginya kepuasan konsumen akan mempengaruhi konsumen untuk semakin loyal. 
Hasil penelitian di atas konsisten dengan teori yang disampaikan oleh Priansa (2017) yang menyatakan bahwa konsumen yang memiliki kepuasan yang tinggi biasanya akan setia lebih lama, membeli lebih banyak ketika perusahaan memperkenalkan produk baru berbicara baik mengenai perusahaan, dan tidak sensitif terhadap harga. Pemaparan tersebut sejalan dengan Tjiptono (2014) yang menyatakan loyalitas konsumen tercipta manakala konsumen membeli barang atau jasa dari sumber yang sama dari waktu ke waktu dan kepuasan pelanggan merupakan penyebab utama terbentuknya loyalitas.

Kepuasan pelanggan yang terus-menerus mengarah pada pembinaan hubungan yang baik. Sebagai hasil dari perasaan yang bagus dan benar-benar terpuaskan, besar kemungkinan konsumen akan melakukan pembelian-pembelian yang lain dan memberikan keuntungan bagi perusahaan, sehingga tercipta hubungan yang lebih kuat dalam jangka panjang. Apabila keadaan seperti ini terus berulang maka akan menciptakan lebih banyak perilaku yang mencerminkan loyalitas konsumen (Barnes J. G., 2003).

\section{Pengaruh Kualitas Pelayanan terhadap Loyalitas Konsumen melalui Kepuasan Konsumen}

Hasil analisis data menunjukkan bahwa kualitas pelayanan tidak berpengaruh signifikan terhadap loyalitas konsumen melalui kepuasan konsumen. Hasil tersebut sejalan dengan penelitian Almassawa (2018) yang menyatakan bahwa kualitas pelayanan tidak berpengaruh terhadap loyalitas konsumen serta tidak ada efek mediasi dari kepuasan konsumen terhadap loyalitas konsumen. Penelitian lain yang dilakukan oleh Lusiah, Noviantoro, \& Akbar (2019) serta Putri \& Utomo (2017) mengemukakan bahwa variabel kepuasan konsumen tidak memberikan pengaruh bagi hubungan kualitas pelayanan terhadap loyalitas konsumen.

Hasil penelitian di atas bertolak belakang dengan teori yang dikemukakan oleh Kotler \& Keller (2009) yang menyatakan bahwa semakin tinggi tingkat kualitas, semakin tiggi tingkat kepuasan yang dihasilkan. Konsumen yang sangat puas biasanya tetap setia untuk waktu yang lebih lama. Hal tersebut menjelaskan bahwa kualitas pelayanan akan mempengaruhi tingkat kepuasan konsumen dimana konsumen yang semakin puas cenderung akan semakin setia atau menunjukkan sikap loyalitas konsumen.

Hal di atas menjelaskan bahwa terdapat kesenjangan antara teori dengan hasil penelitian ini. Kepuasan konsumen diharapkan dapat menjadi mediasi antara pengaruh kualitas pelayanan terhadap loyalitas konsumen, namun hasil penelitian ini menunjukkan sebaliknya. Rangkuti (2003) mengatakan bahwa walaupun suatu jasa berkualitas serta 
memuaskan bagi konsumen, belum tentu jasa tersebut bernilai bagi konsumen. Konsumen semakin loyal apabila jasa yang terima bernilai baginya.

\section{Pengaruh Faktor Emosional terhadap Loyalitas Konsumen melalui Kepuasan Konsumen}

Hasil analisis data menunjukkan bahwa faktor emosional berpengaruh positif dan signifikan terhadap loyalitas konsumen melalui kepuasan konsumen. Hasil tersebut sejalan dengan penelitian terdahulu yang dilakukan oleh Ghorbanzadeh \& Rahehagh (2020) yang menyatakan bahwa kepuasan konsumen dan keterikatan emosional konsumen saling berhubungan dalam mengembangkan loyalitas konsumen. Hasil penelitian lain dilakukan oleh Maulidina \& Sanaji (2020) menyatakan bahwa kepuasan konsumen memiliki pengaruh untuk memediasi antara keterikatan emosi dan loyalitas konsumen.

Hasil penelitian ini konsisten dengan teori yang dinyatakan oleh Barnes (2003) bahwa kepuasan yang dirasakan konsumen ketika berhubungan dengan para pelaku bisnis sangat dipengaruhi oleh sentuhan emosi dari hubungan tersebut. Lebih lanjut Kotler \& Keller (2009) menyatakan bahwa kepuasan atau kesenangan yang tinggi akan menciptakan ikatan emosional pada konsumen. Ikatan emosional yang tinggi terhadap perusahaan akan membuat konsumen cenderung loyal. Konsumen yang loyal secara emosional akan memaafkan kesalahan-kesalahan kecil dalam pengalamannya menjalin hubungan dengan perusahaan (Priansa, 2017).

\section{Pengaruh Persepsi Harga terhadap Loyalitas Konsumen melalui Kepuasan Konsumen}

Hasil analisis data menunjukkan bahwa persepsi harga tidak berpengaruh signifikan terhadap loyalitas konsumen melalui kepuasan konsumen.Hasil tersebut sejalan dengan penelitian Purnama, Herawati, \& Kurniawan (2019) serta Lie, Sudirman, Efendi, \& Butarbutar (2019) yang menyatakan bahwa persepsi harga tidak berpengaruh positif signifikan terhadap loyalitas konsumen melalui kepuasan konsumen sebagai variabel intervening. Penelitian terdahulu dengan hasil yang berbeda dilakukan oleh Budiastari (2018) serta Septiani (2020) yang menemukan hasil bahwa persepsi harga berpengaruh terhadap loyalitas konsumen melalui kepuasan konsumen sebagai variabel intervening.

Hasil penelitian ini bertolak belakang dengan teori yang menyampaikan bahwa nilai harga merupakan salah satu determinan utama dalam pembentukan loyalitas konsumen. Nilai harga merupakan perbandingan dari apa yang dibayarkan dengan manfaat yang diterima. (Tjiptono, 2014). Salah satu cara perusahaan memenangkan konsumen yang 
setia adalah dengan mengenakan harga yang cukup rendah untuk penawaran yang berkualitas tinggi (Kotler \& Keller, 2009). Konsumen akan menimbang keuntungan yang mungkin mereka dapat dibandingkan dengan biaya yang sedang atau mungkin dikeluarkan. Konsumen akan merasa puas apabila harga yang dibayarkan memberikan manfaat yang menguntungkan bagi mereka (Barnes J. G., 2003).

\section{Simpulan}

Berdasarkan hasil penelitian yang telah dilakukan, maka kesimpulan yang dapat diambil dari penelitian ini adalah kualitas pelayanan berpengaruh positif dan signifikan terhadap kepuasan konsumen; faktor emosional berpengaruh positif dan signifikan terhadap kepuasan konsumen; persepsi harga berpengaruh positif dan signifikan terhadap kepuasan konsumen; kualitas pelayanan berpengaruh positif dan signifikan terhadap loyalitas konsumen; faktor emosional tidak berpengaruh signifikan terhadap loyalitas konsumen; persepsi harga tidak berpengaruh signifikan terhadap loyalitas konsumen; kepuasan konsumen berpengaruh positif dan signifikan terhadap loyalitas konsumen; kualitas pelayanan tidak berpengaruh signifikan terhadap loyalitas konsumen melalui kepuasan konsumen; faktor emosional berpengaruh positif dan signifikan terhadap loyalitas konsumen melalui kepuasan konsumen; persepsi harga tidak berpengaruh signifikan terhadap loyalitas konsumen melalui kepuasan konsumen.

\section{Saran}

Berdasarkan penelitian yang telah dilakukan diketahui bahwa kualitas pelayanan dan kepuasan konsumen memiliki pengaruh yang besar terhadap loyalitas konsumen. Bagi perusahaan, disarankan untuk lebih meningkatkan pelayanan yang diberikan dengan cara lebih memperhatikan kebutuhan konsumen, tanggap dan cepat dalam pemberian pelayanan, ramah dan bersikap sopan terhadap konsumen. Kualitas pelayanan yang baik dapat meningkatkan kepuasan konsumen dan mendorong konsumen untuk lebih loyal terhadap perusahaan. Bagi peneliti selanjutnya yang tertarik dengan tema kepuasan dan loyalitas konsumen disarankan untuk lebih memperhatikan faktor lain yang dapat mempengaruhi kepuasan dan loyalitas konsumen dan belum dijelaskan dalam penelitian ini. Selain itu, pemilihan sampel juga perlu diperhatikan supaya proses pengumpulan data dapat berjalan dengan lancar. Apabila proses pengambilan data menggunakan teknologi maka bagi konsumen lanjut usia disarankan untuk diberikan pendampingan supaya tidak mengalami kesulitan. 


\section{Daftar Pustaka}

Afthanorhan, A., Awang, Z., Rashid, N., Foziah, H., \& Ghazali, P. L. (2019). Assessing the effects of service quality on customer satisfaction . Management Science Letters, 13-24. doi:10.5267/j.msl.2018.11.004

Akbar, I. (2019). Pengaruh Kualitas Pelayanan, Sarana dan Prasarana terhadap Kepuasan serta Dampaknya terhadap Loyalitas Konsumen pada Industri Perhotelan di Banda Aceh. Jurnal Manajemen dan Akuntansi, 5, 1-7.

Almassawa, S. P. (2018). Pengaruh Kualitas Pelayanan, Citra Perusahaan dan Implikasi Kepuasan Pelanggan terhadap Loyalitas Pelanggan. Jurnal KREATIF : Pemasaran, Sumberdaya Manusia dan Keuangan, 6(3), 69-84.

Amanah, D., \& Harahap, D. A. (2019). Loyalitas Konsumen: Implikasi dari Diferensiasi Produk dan Nilai Emosional. Jurnal Ilmiah Manajemen Dan Bisnis, 20, 15-26.

Aulawi, H. (2016). Kepuasan Konsumen, Biaya Berpindah, Persepsi Harga, dan Citra Perusahaan terhadap Loyalitas Konsumen pada Penyedia Jasa Internet Telkom Speedy. Jurnal Administrasi Kantor, 4, 93-116.

Barnes, J. (2003). Secrets of Customer Relationship Management. Yogyakarta: Andi.

Budiastari, S. (2018). Pengaruh Kualitas Produk, Persepsi Harga, dan Citra Merek terhadap Kepuasan dan Loyalitas Pelanggan Beton Siap Pakai Hollcim di Jakarta. Jurnal Dinamika Manajemen dan Bisnis, 1(1), 87-106.

Chou, S.-K., Kohsuwan, P., \& Thanabordeekij, P. (2019). The Impact of Corporate Image, Service Quality, Trust, and Perceived Value on Chinese Customer Satisfaction and Loyalty: Medical Services in Thailand. Human Behavior, Development and Society, 20(3), 41-51.

Djajanto, L., Afiatin, Y., \& Haris, Z. A. (2019). The impact of relationship marketing on customer value, satisfaction and loyalty: evidence from banking sector in Indonesia. International Journal of Economic Policy in Emerging Economies, 12(2), 207-214.

Erwin, \& Sitinjak, T. (2017). Kontribusi Kualitas Jasa, Kepercayaan dan Kepuasan Konsumen dalam Menciptakan Loyalitas Konsumen. Jurnal Manajemen, 13, 85-191.

Ghorbanzadeh, D., \& Rahehagh, A. (2020). The role of emotional structures in the relationship between satisfaction and brand loyalty. Cogent Psychology, 7, 1-19. doi: https://doi.org/10.1080/23311908.2020.1782098

Ghozali, I. (2014). Structural Equation Modeling Metode Alternatif dengan Partial Least Squares (PLS). Semarang: Universitas Diponegoro.

Ghozali, I., \& Latan, H. (2015). Partial Least Squares Konsep, Teknik dan Aplikasi Menggunakan Program SmartPLS 3.0 untuk Penelitian Empiris. Semarang: Universitas Diponegoro. 
Philanthropy Journal of Psychology

Vol 5 Nomor 1 (2021), 109-130

ISSN 2580-6076 (Print), ISSN 2580-8532 (Online)

Griffin, J. (2016). Customer Loyalty: Menumbuhkan dan Mempertahankan Kesetiaan Pelanggan. Jakarta: Erlangga.

Iksanudin, M., Puspitasari, I., \& Ariningsih, E. P. (2019). Pengaruh Nilai Pelanggan, Kualitas Pelayanan, dan Kedekatan Emosional terhadap Loyalitas Nasabah Bank BNI di Purworejo. Volatilitas, 1, 1-14.

Indrasari, M. (2019). Pemasaran dan Kepuasan Pelanggan. Surabaya: Unitomo Press.

Irawan, H. (2003). Prinsip Kepuasan Pelanggan. Jakarta: Elex Media Komputindo.

Irawan, Sulistyono, S., \& Tanjung, P. (2019). Pengaruh Persepsi Harga, Kualitas Produk, dan Kepuasan Pelanggan terhadap Loyalitas Pelanggan pada PT. Schneider Electric-Cikarang Plant. Jurnal Manajemen Kewirausahaan, 16(2), 179-188.

Kasiri, L. A., Cheng, K. T., Sambasivan, M., \& Sidin, S. M. (2017). Integration of Standardization and Customization: Impact on Service Quality,. Journal of Retailing and Consumer Services, 35, 91-97.

Kemenag. (2020). Pencarian PPIU (Penyelenggara Perjalanan Ibadah Umrah). Diambil kembali dari https://simpu.kemenag.go.id/home/travel

King, L. (2017). Psikologi Umum : Sebuah Pandangan Apresiatif. Jakarta: Salemba Humanika.

Kotler, P., \& Keller, K. (2009). Manajemen Pemasaran. Jakarta: Erlangga.

Le, D. N., Nguyen, H. T., \& Truong, P. H. (2019). Port logistics service quality and customer satisfaction: Empirical evidence from Vietnam. The Asian Journal of Shipping and Logistics, 1-15. doi:https://doi.org/10.1016/j.ajsl.2019.10.003

Lie, D., Sudirman, A., Efendi, \& Butarbutar, M. (2019). Analysis of Mediation Effect Of Consumer Satisfaction On The Effect Of Service Quality, Price and Consumer Trust On Consumer Loyalty. International Journal of Scientific \& Technology Research, $8(08), 421-428$.

Lupiyoadi, R. (2017). Pemasaran Jasa. Tangerang Selatan: Universitas Terbuka.

Lusiah, Noviantoro, D., \& Akbar, A. (2019). Pengaruh Kualitas Pelayanan Terhadap Loyalitas Pelanggan Melalui Kepuasan Pelanggan Jasa Transportasi Online. Jurnal Ekonomi, XXIV(02), 213-226. doi:http://dx.doi.org/10.24912/je.v24i2.574

Maulidina, L. L., \& Sanaji, S. (2020). Peran Mediasi Kepuasan Pelanggan pada Pengaruh Keterikatan Emosi terhadap Loyalitas Pelanggan Rolag Kopi Kayoon Surabaya. Jurnal Ilmu Manajemen, 8(4), 1362-1371.

Meesala, A., \& Paul, J. (2016). Service Quality, Consumer Satisfaction and Loyalty in Hospitals: Thinking for the future. Journal of Retailing and Consumer Services, 1-9.

Molle, M. A., Mandey, S. I., \& Kojo, C. (2019). Pengaruh Kepuasan Konsumen terhadap Loyalitas Konsumen pada Royal's Resto and Function Hall di Kota Ternate. Jurnal $E M B A, 7,871-880$. 
Moreo, A., Woods, R., Sammons, G., \& Bergman, C. (2018). Connection or competence: Emotional labor and service quality's impact on satisfaction and loyalty. International Journal of Contemporary Hospitality Management, 1-19. doi:10.1108/IJCHM-03-2017-0176

Nurrahman, A., Eldine, A., \& Muniroh, L. (2019). Pengaruh Persepsi Harga dan Kualitas Pelayanan terhadap Kepuasan Konsumen. Jurnal Ilmu Manajemen, 2(2), 575-584.

Othman, B., Harun, A., Taha, M. Y., Aref, K. F., \& Sadq, Z. M. (2020). The Relationship Between Umrah Service Quality Dimensions and Umrah Customer Loyalty: A Studi on the Umrah Travelling Industry in Malaysia . Journal of Critical Reviews, 7(13), 2131-2142.

Pakurar, M., Haddad, H., Nagy, J., Pop, J., \& Olah, J. (2019). The Service Quality Dimensions that Affect Customer Satisfaction in the Jordanian Banking Sector. Sustainability, 11, 1-24. doi:doi:10.3390/su11041113

Pourazad, N., Stocchi, L., \& Pare, V. (2019). Brand Attribute Associations, Emotional Consumer-Brand Relationship and Evaluation of Brand Extensions. Australasian Marketing Journal, 1-12.

Priansa, D. J. (2017). Dalam Perilaku Konsumen dalam Bisnis Kontemporer. Bandung: Alfabeta.

Prihatin, Y. T., Mursito, B., \& Wijayanti, A. (2018). Pengaruh Kualitas Produk, Kualitas Pelayanan dan Faktor Emosi terhadap Kepuasan Pelanggan Di UD Toko Pelangi Surakarta. Indonesian Economics Business and Management Research, 1, 100-103.

Prihatin, Y. T., Mursito, B., \& Wijayanti, A. (2018). Pengaruh Kualitas Produk, Kualitas Pelayanan dan Faktor Emosi Terhadap Kepuasan Pelanggan Di UD Toko Pelangi Surakarta. Indonesian Economics Business and Management Research, 1(1), 100103.

Purnama, S. D., Herawati, J., \& Kurniawan, S. (2019). Pengaruh Persepsi Harga dan Kualitas Produk terhadap Loyalitas Pelanggan melalui Kepuasan Pelanggan sebagai Variabel Intervening pada Telkom Indonesia Wifi Corner Kotabaru Yogyakarta. Jurnal Manajemen Dewantara, 3(1), 171-180.

Putri, Y. L., \& Utomo, H. (2017). Pengaruh Kualitas Pelayanan terhadap Loyalitas Pelanggan dengan Kepuasan sebagai Variabel Intervening. Among Makarti, 10(19), 70-90.

Rangkuti, F. (2003). Measuring Customer Satisfaction. Jakarta: Gramedia.

Repiannur, Rachma, N., \& Khoirul, M. (2020). Analisis Pengaruh Nilai Pelanggan,Kualitas Pelayanan Dan Kedekatan Emosional Terhadap Loyalitas Pelanggan. e-Jurnal Riset Manajemen, 29-47.

Ritonga, H. M., Pane, D. N., \& Rahmah, C. A. (2020). Pengaruh Kualitas Pelayanan dan Emosional terhadap Kepuasan Pelanggan pada Honda IDK 2 Medan. Jurnal Manajemen Tools, 12(2), 30-44. 
Rivai, A. R., \& Wahyudi, T. A. (2017). Pengaruh Persepsi Kualitas, Citra Merek, Persepsi Harga terhadap Loyalitas Pelanggan dengan Kepercayaan dan Kepuasan Pelanggan sebagai Variabel Mediasi. Jurnal Bisnis dan Komunikasi , 4, 29-37.

Salim, M. A., Soliha, E., \& Siswanto, A. B. (2020). Effect Location, Price Perception of Satisfaction Customers and Impact on Repurchase Intention. International Journal of Civil Engineering and Technology, 11(5), 157-169.

Sari, N. P. (2017). Pengaruh Kualitas Pelayanan dan Persepsi Konsumen terhadap Loyalitas Konsumen dengan Kepuasan Konsumen sebagai Variabel Intervening pada Eka Prima Motor Pematangsiantar. Jurnal SULTANIST, 6, 26-37.

Sari, N., Priyatama, A. N., \& Satwika, P. A. (2019). Loyalitas Pelanggan Maskapai Penerbangan Ditinjau dari Kualitas Layanan dan Emotional Branding. Analitika: Jurnal Magister Psikologi UMA, 11, 98-103.

Savitri, I. A., \& Wardana, I. M. (2018). Pengaruh Citra Merek, Kualitas Produk dan Persepsi Harga terhadap Kepuasan dan Niat Beli Ulang. E-Jurnal Manajemen Unud , 7, 57485782.

Septiani, R. (2020). Pengaruh e-Service Quality Persepsi Harga, dan Promosi Penjualan terhadap Loyalitas Pelanggan melalui Kepuasan Pelanggan. Jurnal Ilmu Manajemen, 17(2), 98-108.

Sobur, A. (2003). Psikologi Umum. Bandung: Pustaka Setia.

Sugiyono. (2018). Metode Penelitian Kuantitatif. Bandung: Alfabeta.

Sulistiyanto, \& Munisih, S. (2018). Pengaruh Persepsi Harga dan Citra Perusahaan terhadap Kepuasan dan Loyalitas Pelanggan Pedagang Besar Farmasi PT. Sakapilar Semarang. Media Farmasi Indonesia, 13(1), 1277-1283.

Suryati, L. (2019). Manajemen Pemasaran : Suatu Strategi Dalam Meningkatkan Loyalitas. Yogyakarta: Deepublish.

Susanti, V., Sumarwan, U., Simanjuntak, M., \& Yusuf, E. Z. (2020). How to anticipate and manage customer satisfaction and brand loyalty by investigating emotional aspects in the B2B setting. Management Science Letters, 10, 3271-3278. doi:doi: 10.5267/j.msl.2020.6.011

Tjiptono, F. (2014). Pemasaran Jasa - Prinsip, Penerapan, dan Penelitian (hal. 393). Yogyakarta: Andi.

Widyasari, S., Soliha, E., Wuryan, S., \& Damayanti, L. D. (2017). Pengaruh Kualitas Produk, Persepsi Harga dan Citra Merk Terhadap Kepuasan Serta Dampaknya Pada Loyalitas Pelanggan (Studi Empiris Pada Koran Harian Suara Merdeka di Kota Semarang). Jurnal Manajemen Bisnis Indonesia, 5, 117-132.

Winarno, S. H., Nalendra, A. R., \& Givan, B. (2020). The Effect of Service Quality, Corporate Image, and Price Perceived in Creating Customer Satisfaction and Loyalty on Education Business. Jurnal Bisnis dan Manajemen, 10(1), 45-56. 
Philanthropy Journal of Psychology

Vol 5 Nomor 1 (2021), 109-130

ISSN 2580-6076 (Print), ISSN 2580-8532 (Online)

Zikmund, W. G., Mcleod, R., \& Gilbert, F. W. (2003). Dalam Customer Relationship Management-Integrating Marketing Strategy and Information Technology. New Jersey: Wiley. 